\title{
Food Online Business Challenges During the Pandemic in Medan City
}

\section{Tantangan Bisnis Online Makanan Selama Pandemi di Kota Medan}

\author{
Yudi Bimantaka1); Sugeng Arifandi Banurea'); Nurbaiti ${ }^{3)}$ \\ 1,2) Universitas Islam Negeri Sumatera Utara, Medan
}

Email: 1yudibimantaka3682@gmail.com, ${ }^{2}$ sugengarifandi9@gmail.com, ${ }^{3}$ nurbaiti@uinsu.ac.id

How to Cite :

Bimantaka, Y., Banurea, S. A., Nurbaiti. (2022). Food Online Business Challenges During the Pandemic in Medan City. Jurnal Ekonomi Manajemen Akuntansi Dan Keuangan, 3(1). DOI: https://doi.org/10.53697/emak.v3i1

ARTICLE HISTORY

Received [1 Desember 2021]

Revised [10 Desember 2021]

Accepted [28 Desember 2021]

\section{KEYWORDS}

Survival Strategy, Micro

Business, Internet

This is an open access article under the $C C-B Y$-SA license

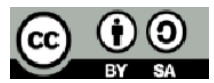

\section{ABSTRAK}

Penelitian ini bertujuan untuk mengetahui tantangan bisnis makanan dengan menggunakan e-business di kota medan dan beberapa mahasiswa UINSU yang berjualan makanan atau jajanan kecil kecilan. Penelitian ini mengunakan kualitatif deskriftif dengan mengumpulkan data observasi, dokumentasi, dan wawancara. Hasil penelitian menunjukkan : 1) masih bisa berjualan online saat seperti ini (covid 19). 2) tantangan yang umum di rasakan atau di alami ialah, konsumen yang ingin serba cepat dan instan, merasa takut gagal dalam mencoba hal baru seperti berjualan online di saat pandemi seperti ini, harus ekstra dalam menarik pelanggan yang tidak seperti biasanya. 3) ada cara untuk menghadapi tantangan tersebut yaitu dengan mempromosikan dagangan melalu media sosial walaupun harus menambah biaya untuk melakukan promosi tersebut.

\section{ABSTRACT}

This research aims to find out the challenges of food business by using ebusiness in the city of Medan and some UINSU students who sell food or small snacks. This study uses qualitatively derifrift by collecting observational data, documentation, and interviews. The results showed: 1) can still sell online at this time (covid 19). 2) The common challenge felt or experienced is, consumers who want to be fast and instant, feel afraid of failing in trying new things such as selling online in times of pandemic like this, must be extra in attracting customers who are not as usual. 3) There is a way to deal with these challenges by promoting merchandise through social media even though it has to increase the cost to do the promotion

\section{PENDAHULUAN}

Di masa pandemi Covid19, sistem pemesanan dan pengantaran makanan secara online menjadi salah satu alternatif untuk memenuhi kebutuhan pangan konsumen tanpa keluar rumah sekaligus mendongkrak perekonomian nasional. Akibatnya, keamanan pangan, risiko paparan virus, dan kelangsungan hidup makanan tetap menjadi tantangan untuk membuat ini berhasil dengan begitu banyak produk dari industri makanan yang belum diidentifikasi sertifikasi halal.

Untuk menguatkan keamanan makanan pada jasa antar makanan online, pemerintah di setiap daerah harus mengurangi halangan masuk pasar bagi para pelaku bisnis makanan online. Proses sertifikasi pasar harus sederhana, melakukan pemahaman terhadap keamanan pangan yang semsetinya, dan memberikan pengawasan serta penelusuran isu-isu keamanan pangan. Bersamasama dengan pihak swasta membentuk struktur kerja keamanan pangan. Yang dimana pengaturan 
tersebut memudahkan penerapan umum keamanan pangan dan memenuhi persiapan peraturan bersama kemauan sektor swasta. Hal ini wajib disahkan di dalam bahasan Rancangan UndangUndang (RUU) Pengawasan Pangan dan Obat-Obatan.

Orang-orang masi takut terhadap makanan yang dijual di rumahan karena belum terlihat adanya standar kebersihan keamanan sudah kehigenisan nya, maka sangat perlu adanya pengembangan terhadap kuliner-kuliner yang ada di kota medan ini untuk memajukan perekonomian dan mensejahterakan masyarakat. Masyarakat selalu berpendapat bahwasannya masakan di rumah lebih higenis dari pada makanan di luar sana, terlebih di saat pandemi seperti ini orang-orang akan lebih memilih masakan di rumahnya masing-masing dari pada harus beli makanan diluar dengan memesan online. Maka ini menjadi tantangan bagi pelaku bisnis makanan online yang ada dikota medan agar mereka tetap bisa berjualan dan memiliki pendapatan yang semestinya sebelum terjadinya pandemi covid 19 saat ini.

Disini mencari apa saja tantangan yang dihadapi oleh pelaku bisnis makanan yang ada dikota medan dengan mewawancarai para pelaku bisnis. Dengan mewawancarai pelaku bisnis maka akan kami dapatkan informasi yang terkait dengan judul kami atau bahkan kami bisa menemukan solusi bagi pelaku bisnis yang menggunakan e-bisiness.

\section{LANDASAN TEORI}

\section{E-Business}

Istilah EBusiness biasanya mengacu pada penggunaan Internet untuk tujuan bisnis atau bisnis. Ada kesamaan antara istilah dan email, e-commerce, karena keduanya menggunakan Internet. Istilah yang lebih umum untuk e-commerce, tidak hanya berfokus pada pembelian dan penjualan, tetapi juga pada layanan pelanggan dan bekerja dengan mitra bisnis. Dalam definisi yang paling sederhana, e-commerce adalah penggunaan teknologi internet untuk meningkatkan dan membentuk kembali proses bisnis utama. Sebagian besar bisnis sudah mulai beralih dari cara bisnis tradisional atau konvensional ke e-commerce.

Penggunaan teknologi berbasis e-commerce menyederhanakan operasi bisnis dan meningkatkan kualitas produksi. Penerapan teknologi ini dapat memperluas pangsa pasar perusahaan terutama biaya promosi yang murah dibandingkan dengan promosi di jalan atau di media massa. Hanya sosialisasi ekstensif dan pembelajaran serta persiapan menyeluruh yang diperlukan sebelum menerapkan aplikasi e-bisnis. Kelemahan e-commerce dapat ditangani dengan hati-hati, tetapi dibutuhkan lebih dari sekadar rencana yang matang, serta pakar profesional untuk mengatasinya. Perusahaan yang tidak mau beralih ke teknologi ini lambat laun akan kewalahan menghadapi era pasar bebas di masa depan.

\section{Usaha Kuliner}

Bisnis kuliner merupakan salah satu profesi yang tidak pernah ada habisnya, karena kapanpun manusia membutuhkan makanan untuk hidup. Oleh karena itu, peluang ini harus dimanfaatkan sebaik-baiknya untuk menciptakan bisnis kuliner yang menguntungkan pengusaha. Jika Anda memulai bisnis katering, konsep yang sedang dibangun tidak boleh hanya didasarkan pada lokasi. Ada banyak hal lain yang perlu diperhatikan agar bisnis berjalan dengan baik. Bisnis kuliner merupakan bisnis yang menguntungkan dan selalu diminati, alasannya karena makanan merupakan kebutuhan pokok manusia yang tidak dapat dipisahkan dari kehidupan kita. Bisnis makanan ini juga mencakup berbagai kategori, mulai dari makanan ringan dan minuman hingga makanan pokok. Semua kategori kegiatan kuliner ini (jajanan, minuman, makanan pokok) memiliki potensi yang sangat bagus, tergantung bagaimana kita memasarkannya.

\section{Berjualan online (E-Bisiness)}

bisnis online adalah bisnis yang dijalankan melalui internet. Artinya, aktivitas bisnis seperti jual-beli, pelayanan kepada konsumen, promosi, dan sebagainya dilakukan secara 
online. Menariknya, Anda bisa menjual berbagai jenis produk melalui bisnis online. Mulai dari barang, jasa, hingga produk digital. Bahkan, tak ada batasan dari mana calon konsumen produk untuk tersebut. Sebab, pembeli produk bisa berasal dari seluruh Indonesia, bahkan dari luar negeri.

\section{Tantangan /Halangan}

Tantangan yang kami maksud disni yaitu masalah yang di dapat selama berjualan makanan online, apa perlu dilakukan para pelaku bisnis makanan di era serba digital saat ini, apakah mereka bisa bertahan dalam keadaan yang seperti ini, dikarenakan sebelumnya mereka hanya berjualan offline atau sama sekali tidak menggunakan teknologi digital.

Apa yang harus dilakukan untuk melewati tantangan ini, hanya ada 2 pilihan yaitu harus dilalui dan merubahnya atau hanya berdiam dan pasrah apa yang akan terjadi, kalah dalam persaingan dan menonton para pelaku bisnis lainnya

\section{Metode Analisis}

\section{METODE PENELITIAN}

Penelitian kualitatif adalah metode untuk menemukan dan memahami makna yang diberikan oleh individu atau kelompok tertentu terhadap masalah sosial atau kemanusiaan. Proses penelitian kualitatif ini melibatkan upaya yang cukup besar, seperti mengajukan pertanyaan dan prosedur, mengumpulkan data spesifik dari partisipan, menganalisis data secara bijaksana dari topik khusus, ke topik umum, dan menjelaskan makna data. Penelitian ini dilakukan di wilayah Kota Medan, Kota Medan yang terletak di provinsi Sumatera Utara, di pulau Sumatera. Subyek penelitian ini adalah warga daerah Medan Denai dan sekitarnya. Teknik pengumpulan data yang diterapkan dalam penelitian ini. Wawancara, observasi, dokumentasi

\section{HASIL DAN PEMBAHASAN}

Menurut hasil observasi terdapat 5 Bisnis jualan makanan online yang telah kami lakukan wawancara yaitu :

a. Warung Rosojoyo

Warung Rosojoyo adalah warung makanan yang menjual makanan mulai dari gorengan sampai dengan aneka mie. Warung Rosojoyo milik Bu Ayu ini sudah dibuka mulai tahun 2015 lalu. Awalnya warung ini hanya berjualan melalui ofline tetapi dikarenakan keadaan dan perkembangan digital Bu Ayu selaku pemilik warung mulai menjual makanan di warungnya melalui online yaitu dengan menawarkan makanannya melalui media social facebook, whatsapp, dan instagram. Bu Ayu merasakan saat sekarang ini persaingan dan tantangan dengan berjualan online sudah semakin ketat.

b. Warung ayam geprek berkah

Warung ayam geprek berkah milik pak Ready Saranan seorang mahasiswa dari UINSU berdiri pada awal bulan oktober di tahun 2021, di warung ayam geprek berkah tersebut menjual lontong, ayam geprek, salad, dan bakso. Selain berjualan oflline pak Ready juga menawarkan jualannya di gofood dan grabfood serta mempromosikan di media social seperti whatsapp dan instagram.

c. Usaha popcorn jaya

Usaha popcorn jaya adalah usaha jualan makanan ringan milik pak Rafly, usaha ini dimulai pada tahun 2019 lalu. Usaha makanan ringan ingin telah memasarkan barangnya di social media seperti whatsapp, instagram, dan facebook. Pak Rafly mengatakan di era yang serba didgital saat ini kita tidak boleh hanya pasrah dengan keadaan tetapi harus ikut mengambil bagian di persaingan yang serba online ini. Usaha makanan ringannya ini sudah sangat di kenal di kalangan pecinta jajanan di kota Medan.

d. Dapur cokelat 
Dapur coklat adalah toko kue yang baru saja didirkan pada tahun 2020 lalu oleh seorang mahasiswa aktif UINSU. Dapur cokelat ini menjual aneka ragam kue mulai dari kue ulang tahun sampai kue lokal dan sudah lumayan dikenal dikalangan masyarakat dan mahasiwa. Dapur cokelat sendiri memasarkan barangnya dengan bergabung menjadi mitra di gofood dan grabfood serta sering memajang iklan di social media seperti whatsapp, instagram, dan facebook.

e. Martabak terang bulan

Martabak terang bulan adalah usaha yang dibuat oleh pak ahmad, ia mulai menjalankan bisnis ini pada tahun 2017 lalu. Usahanya ini ia jalankan melalui offline dan juga online. Pemasaran online yang dilakukan pak Ahmad adalah dengan join bersama pihak grabfood dan gofood.

Dalam wawancara yang kami lakukan terhadap pemilik usaha makanan di sekitaran kota medan dan dengan beberapa mahasiswa kami mendapat jawaban dari para narasumber tentang tantangan-tantangan yang di hadapi dan cara-cara menghadapinya selama bergelut di usaha bisnis makanan secara online.

1. Alasan memilih berjualan secara online

Rata-rata alasan para pelaku usaha bisnis makanan berjualan secara online adalah dikarenakan keadaan pandemi dan diberlakukannya PPKM di kota medan, serta saat sekarang ini banyak masyarakat yang lebih menyukai membeli makanan via online karena lebih menghemat waktu mereka.

Warung Rosojoyo memilih untuk melakukan pemasaran melalui social media dikarenakan di berlakukannya PPKM di kota Medan yang membuat warungnya yang semula ramai pengunjung menjadi sepi dan menuntutnya untuk melakukan penjualan secara online (Bu Ayu 20 oktober 2021)

Warung ayam geprek berkah Alasan warung ayam geprek berkah melakukan penjualan melalui online adalah dikarenakan mereka menyadari di era serba digital ini banyak masyarakat yang tidak memiliki waktu untuk datang langsung ke tampat makan dan lebih memilih untuk memesan makanan via online atau aplikasi ditambah dengan keadaan pandemi juga. (pak Readi 20 oktober 2021)

Usaha popcorn jaya memilih untuk melakukan pemasaran secara online dikarenakan kemudahan yang di tawarkan jika berjualan secara online yaitu waktu yang digunakan lebih fleksibel dan tidak memakan tempat dan juga konsumen yang di gapai lebih luas sehingga dapat mencapai target pemasaran(Rafly 20 oktober 2021)

Dapur coklat mengatakan alasan mereka untuk joim dengan pihak gofood dan grabfood adalah untuk mendapatkan konsumen yang lebih luas dan dengan bergabung dengan mitra tersebut mereka menjadi lebih mudah dalam proses pengiriman barang kemana saja ( Nabila 20 oktober 2021)

Martabak terang bulan, pendapatan Pak Ahmad dari usahanya ini sangat turun drastis semenjak di berlakukannya PPKM di kota medan dan dia mengambil solusi untuk meningkatkan kembali pendapatan dari usahanya adalah dengan menjual makanannya melalui via aplikasi yaitu dengan bergabung dengan pihak gofood dan grabfood (Pak Ahmad 20 oktober 2021)

Berdasarkan hasil wawancara yang telah kami lakukan kepada para pelaku usaha bisnis makanan melalui online di kota Medan dan beberapa mahasiswa dari UINSU kami dapat menarik kesimpulan bahwa alasan para pelaku bisnis ini melakukan usaha nya melalui online sebagian besar dikarenakan oleh kemajuan era digital dan juga disebabkan oleh pandemic yang sedang melanda sert ada juga yang mengatakan jika berjualan dengan online waktu yang di gunakan lebih flaksibel dan capaian dari bisnis secara online ini sangat luas.

Para pelaku bisnis ini banyak memasarkan jualannya melalui aplikasi seperti gofood, grabfood, whatsapp, instagram dan juga facebook. Para pelaku usaha ini merasa sangat terbantu oleh aplikasi-aplikasi tersebut.

2. Tantangan-tantangan yang dihadapi selama berjualan secara online

118 | Yudi Bimantaka, Sugeng Arifandi Banurea, Nurbaiti; Food Online Business Challenges... 
Di era yang serba digital sekarang ini para pelaku bisnis makanan harus mampu melakukan yang terbaik guna menarik minat para konsumen untuk membeli ditempat mereka. Dalam mencapai itu semua tentunya banyak sekali tantangan yang harus di hadapi. Dari wawancara yang kami lakukan pada 20 oktober 2021 kepada para pelaku bisnis makanan secara online ini, kami mendapat jawaban tentang banyaknya tantangan yang harus mereka hadapi, tantangan yang mereka hadapi di mulai dari, ketatnya persaingan di dunia bisnis kuliner online, cara memahami keinginan oara konsumen, mengikuti tren yang berkembang, dan cara menarik minat para pelanggan serta banyak lainnya.

Berikut ini pernyataan dari para responden yang kami wawancarai :

Tantangan yang saya hadapi selama berjualan online ini sangan banyak mulai dari rasa takut gagal karena kita harus mencoba hal baru, harus memahami dunia internet, saya yang dulunya tidak terlalu memahami tentang internet sekarang harus belajar mengikuti era dimana semua serba online, itu tantangan yang harus hadapi selama malakukan usaha jualan makanan selama online. (Bu Ayu pemilik warung Rosojoyo)

Pernyataan yang di sampaikan oleh pak Readi sebagai pemilik warung ayam geprek berkah juga hampir sama tantangan yang ia hadapai yaitu harus mampu memenuhi keinginan pelanggan dimana semua harus serba cepat dan praktis, tantangan utama yang di hadapi adalah menarik pelanggan untuk mau membeli di warung kita, ini adalah hal yang harus di pikirkan dengan baik ,tuturnya.

Pak Rafly selaku pemilik usaha popcorn jaya mengatakan tantangan utama yang di hadapi dalam menjalankan bisnisnya adalah banyaknya pesaing yang mulai bermunculan, sebagai pemilik usaha popcorn tentunya harus mampu mengambil bagian di persaingan tersebut dan harus meningkatkan kualitas dan relasi kepada para konsumen.

Pemilik usaha dapur coklat yaitu Bu Nabila mengatakan tantangan yang ia hadapi selama melakukan penjualan secara online adalah dalam proses pengantaran (delivery), proses pengantaran kue dengan makanan lain tentunya sangat berbeda jadi hal utama yang harus di perhatikan adalah bagaimana supaya kue yang di pesan oleh konsumen sampai kepada mereka dengan baik, itu saja tantangan terbesar yang harus saya hadapi ujar Bu Nabila

Pernyataan yang serupa di sampaikan oleh Pak Ahmad sebagai pemilik usaha martabak terang bulan tantangan terbesar yang saya hadapi sellain dari menarik pelanggan adalah proses pengirimannya kepada para pelanggan, tak jarang martabak yang saya jual sampai ke pelanggan tidak seperti yang saya iklankan dikarenakan pengiriman yang kurang baik, tutur nya.

Berdasarkan hasil wawancara yang kami lakukan kepada para pemilik usaha makanan online, dapat disimpulkan tantangan yang di hadapi adalah

- Menarik pelanggann

- Rasa takut gagal karena harus memulai sesuatu yang baru

- Persaingan yang ketat

- Memenuhi keinganan konsumen yang kadang berubah ubah

- Pengiriman yang kadang kurang memuaskan

Dalam mengahadapi tantangan tersebut tentunya setiap usaha memiliki cara tersendiri untuk menghadapinya.

3. Cara menghadapi tantangan

Setelah mengetahui tantangan yang di hadapi kini para pelaku usaha harus mencari cara menghadapi tantangan tersebut. Berikut hasil wawancara yang kami lakukan tentang cara yang di lakukan oleh para pelaku usaha dalam menghadapi tantangan myang mereka hadapi.

Dari tantangan yang kita sebutkan diatas ada berbagai cara dalam menghadapinya seperti Bu Ayu dalam menarik minat pelanggan yaitu dengan memberikan beberapa promosi kepada para konsumen sehingga mereka akan tetap membeli di warungnya, dan tetap berusaha memberikan pelayanan terbaik. 
Pak Readi juga melakukan hal yang sama yaitu memberikan dsikon pembelian kepada para konsumen yang membeli lebih dari 3 kali di tokonya, dan juga ia makin memperbanyak iklan tentang warung yang ia miliki.

Usaha yang di lakukan pak Rafly dalam menghadapi ketatnya persaingan adalah dengan memperbanyak relasi kepada masyarakat dan organisasi-organisasi untuk bisa tetap mempertahankan kelangsungan usahanya.

$\mathrm{Bu}$ Nabila memilih bergabung dengan pihak goofood dan grabfood untuk bisa menghadapi tantangan dalam bisnisnya, dimana pengiriman makanan daru tokonya bisa lebih terjamin dan aman sampai kepada para konsumen dengan memilihi join kepada pihak gofood dan grabfood. Pak Ahmad juga melakukan hal yang sama dengan Bu Nabila menggunakan jasa yang di sediakan oleh pihak grab dan gojek, dan pengirimannya bisa lebih aman.

Dari hasil awancara tersebut dapat diambil kesimpulan usaha-usaha yang di lakukan para pemilik usaha dalam menghadapi tantangan dalam bisnisnya yaitu :

- Memberikan promosi kepada para pelangan tetap agar tidak pindah membeli ke toko lain

- Berusaha memahami kebutuhan para konsumen dengan memberikan pelayanan terbaik

- Memperluas relasi kepada masyarakat dan organisasi-organisasi

- Memilih join dengan beberapa,mitra seperti jasa pengiriman gofood \& grabfood

\section{Kesimpulan}

\section{KESIMPULAN DAN SARAN}

Hasil dari penelitian yang kami lakukan maka penelitian ini dapat kami simpulkan.Tantangan yang besar dihadapi para pelaku usaha ketika system mereka berjualan yang semula hanya secara sederhana yaitu face to face dengan kehadiran teknologi dan semau serba online mebuat para pelaku ini harus mampu mengikuti arus perkembangan teknologi atau sekarang sering di sebut dengan nama E-BUSSINES. Semakin maju teknologi tidak hanya berdampak pada perusahaanperusahaan besar tetapi juga berdampak pada pelaku usaha kecil menengah. Para pelaku usaha harus mampu memanfaatkan semua peluang yang ada untuk mencapai tujuan dari usahanya.

\section{Saran}

Semakin maju teknologi tidak hanya berdampak pada perusahaan- perusahaan besar tetapi juga berdampak pada pelaku usaha kecil menengah. Para pelaku usaha harus mampu memanfaatkan semua peluang yang ada untuk mencapai tujuan dari usahanya

\section{DAFTAR PUSTAKA}

Adi, M Kwartono. 2007. Analisis Usaha Kecil Dan Menengah. Yogyakarta: AndiOffset.

Ari Mulianta Ginting dkk., Strategi Pengembangan Ekonomi Kreatif di Indonesia (Yayasan Pustaka Obor Indonesia, 2018), 7.

Setyowati, Eni. Dkk. 2020. Work From Home. Tulungagung. IAIN Tulungagung Press.

Sunarsi, D. 2020. Implikasi Digitalisasi UMKM. Digitalisasi UMKM, 57.

120 | Yudi Bimantaka, Sugeng Arifandi Banurea, Nurbaiti; Food Online Business Challenges... 